\title{
The prognostic and therapeutic role of hormones in colorectal cancer: a review
}

\author{
Stella Nikolaou ${ }^{1,2,3,4} \cdot$ Shengyang Qiu ${ }^{1,3} \cdot$ Francesca Fiorentino $^{3} \cdot$ Shahnawaz Rasheed ${ }^{1,2,3} \cdot$ Paris Tekkis ${ }^{1,2,3}$. \\ Christos Kontovounisios ${ }^{1,2,3}$
}

Received: 25 August 2018 / Accepted: 23 November 2018 / Published online: 10 December 2018

(c) The Author(s) 2018

\begin{abstract}
Colorectal cancer (CRC) is one of the commonest cancers in Western society with a poor prognosis in patients with advanced disease. Targeted therapy is of increasing interest and already, targeted hormone treatment for breast and prostate cancer has improved survival. The aim of this literature review is to summarise the role of hormones in CRC prognosis and treatment. A literature review of all human and animal in vivo and in vitro studies in the last 20 years, which assessed the role of hormones in CRC treatment or prognosis, was carried out. The hormones described in this review have been subdivided according to their secretion origin. Most of the studies are based on in vitro or animal models. The main findings point to adipokines, insulin and the insulin growth factor axis as key players in the link between obesity, type 2 diabetes mellitus and a subset of CRC. Gut-derived hormones, especially uroguanylin and guanylin are being increasingly investigated as therapeutic targets, with promising results. Using hormones as prognostic and therapeutic markers in CRC is still in the preliminary stages for only a fraction of the hormones affecting the GIT. In light of the increasing interest in tailoring treatment strategies, hormones are an important area of focus in the future of CRC management.
\end{abstract}

Keywords Colorectal $\cdot$ Cancer $\cdot$ Hormones $\cdot$ Prognosis $\cdot$ Treatment

Stella Nikolaou

sn702@ic.ac.uk

Shengyang Qiu

S.qiu@imperial.ac.uk

Francesca Fiorentino

f.fiorentino@imperial.ac.uk

Shahnawaz Rasheed

s.rasheed@imperial.ac.uk

Paris Tekkis

p.tekkis@imperial.ac.uk

Christos Kontovounisios

c.kontovounisios@imperial.ac.uk

1 Department of Colorectal Surgery, Chelsea \& Westminster Hospital, London, UK

2 Department of Colorectal Surgery, Royal Marsden Hospital, London, UK

3 Department of Surgery and Cancer, Imperial College, London, UK

4 Department of Surgery and Cancer, Imperial College London, Royal Marsden Hospital, Fulham Road \& Chelsea and Westminster Campus, 369 Fulham Road, London SW10 9NH, UK

\section{Introduction}

Colorectal cancer (CRC) is one of the commonest cancers in Western society with a median 5-year survival of $10-15 \%$, in patients with advanced disease [1]. Conventional chemotherapy and radiotherapy have improved survival in patients with advanced CRC. However, the risk of recurrence even after microscopically complete (R0) resection can still be as high as $50-75 \%$ in patients with advanced disease [2].

Molecular targeting strategies are of particular interest due to their potential to increase treatment specificity to the tumor.

Hormone therapy in particular, has revolutionized treatment of localized and metastatic breast, ovarian, endometrial and prostate cancer, which can be used in conjunction with other treatments or as a stand-alone therapy. The gastrointestinal tract (GIT) expresses more than 30 hormone genes, making it the largest endocrine organ in the body [3]. In fact, the first two hormones or 'blood-borne chemical messengers' were gastrin and secretin, initially described in the 1900s [3]. Despite this, there is currently no clinical use of hormones as treatment or as prognostic markers in CRC. 
Our aim with this review is to summarise the literature on studies examining the potential of hormones as prognostic and/or therapeutic markers. We highlight the most promising ones in the hope that they can spur further research into their use.

\section{Discussion}

\section{Adipose tissue}

Obesity is considered a risk factor to cancer including CRC and hormones secreted from adipose tissue may exert a tumorigenic effect on the GIT [4]. There are two types of adipose tissue: the white adipose tissue (WAT) and the brown adipose tissue (BAT) [5]. The WAT is known to produce cytokines and hormones, whilst the BAT is highly metabolic and produces heat [5]. The adipokines, like adiponectin and lectin, are proteins with autocrine, paracrine and endocrine function and have been implicated in many diseases including cancer [5].

\section{Adiponectin (APN)}

Adiponectin is a $30 \mathrm{kDa}$ complement C1q-related protein, which is mainly produced by the WAT $[4,6]$. The APN gene is on chromosome $3 \mathrm{q} 27$ and can exist as low molecular weight (LMW) trimers, middle molecular weight (MMW) hexamers or high molecular weight (HMW) multimers before it is secreted [4]. There are three adiponectin receptors: AdipoR1, AdipoR2 and T-cadherin [4]. It is likely that the HMW isoform of APN is the most biologically active isoform. Both MMW and HMW tend to bind to the T-cadherin surface receptor which is linked to cell adhesion and communication via a calcium-dependent mechanism [4].

Low levels of circulating APN in the bloodstream is linked to obesity-related CRC [7]. APN is involved in many other signaling pathways e.g. mTOR, NK-kB, JNK and STAT3 [8] and it suppresses inflammation, insulin resistance, endothelial cell migration and adhesion [5].

The prognostic role of APN and its receptors has conflicting evidence in literature.

There seems to be a consensus that circulating adiponectin is negatively correlated to tumour stage $[9,10]$ and tumour grade [6]. A prospective study by Chong et al. [11] suggests that high circulating, pre-diagnosis APN carries an increased risk of CRC specific and overall mortality. This study was carried out on patients with CRC who provided blood samples prior to their diagnosis [11]. On the other hand, studies investigating tissue expression of APN and their receptors have not had consistent results. In a study of 58 patients with CRC and 30 controls, Ayyildiz et al. [12] found no influence of AdipoR1 and AdipoR2 expression on survival, although they did find a significantly reduced receptor expression in CRC patients. Sakellariou [13] and Gialamas [6] found that AdipoR1 is negatively associated with nodal stage and AdipoR2 is positively associated with TNM and shorter survival in lower stages of disease. In 2018, Chloe et al. showed that increased tissue AdipoR1 messenger ribonucleic acid (mRNA) is associated with increased mortality and shorter OS [14]. Conversely, Ayyildiz et al. [12] showed that tissue AdipoR1 and AdipoR2 have no influence on survival. However only 58 patients were recruited in this study and their body mass index (BMI) was not known [12]. Canhoroz [15] who measured tissue APN expression also showed that this is not associated with DFS. This study was also limited by the small number of patients recruited [15]. T-cadherin receptor which binds the biologically most active HMW isoform is less well studied but was investigated by Duan et al. [16]. He found that T-cadherin promoter methylation status was not associated with stage or lymph node status [16]. Further studies are therefore needed to validate this marker and its role in prognosis.

Adiponectin supplementation has shown promise in suppressing colorectal carcinogenesis, likely through the adiponectin stimulated protein kinase (AMPK) phosphorylation in both in vitro and animal studies [7, 17, 18]. AdipoRon, an APN-like synthetic molecule, which likely acts via the same pathway, has been shown to improve insulin resistance and glucose tolerance, but also has been shown to inhibit pancreatic cancer cell proliferation [19]. Its antiproliferative effects via the AdipoR1 and AdipoR2 receptors could be a potential chemoprevention therapy in CRC, although it still remains to be investigated [19].

\section{Leptin}

This is the most abundant adipokine and is involved in regulating hyperphagy, glucose homeostasis, growth, immune response and angiogenesis [20]. There are six isoforms of the leptin receptor and only two have been linked to intracellular signaling [20]. OB-Rb is the longest isoform of the leptin receptor and is normally produced in the hypothalamus where it controls food intake via appetite regulation [20].

Although leptin's role in colonic tumorigenesis and proliferation has been well studied [21-23], only a few studies investigated its prognostic potential. Paik SS and colleagues showed that a low tissue leptin expression in CRC tissue samples is associated with more advanced disease whilst high tissue leptin expression is associated with a favorable OS and DFS [24]. Uddin et al. [25] showed that tissue $\mathrm{Ob}-\mathrm{R}$ expression is associated with better OS. However not all studies agree. Wang et al. [26] found that leptin/Ob-R expression was associated with later-stage, easy metastasis and lower grade of disease. Jeong WK [27] also found that 
leptin expression was inversely associated with nodal stage but was not associated with differentiation, $\mathrm{T}$ stage and stage of disease. Guadagni et al. [28] looked at both serum leptin and adiponectin levels in patients with primary and metastatic CRC and compared it to controls. They showed that leptin levels were higher than in controls whilst serum ADN was lower than controls, concurring with previous studies $[22,29]$. A low leptin/adiponectin ratio (L/A) was associated with an increased survival compared to patients with high L/A ratio [28]. In patients with metastatic CRC, overall survival was significantly greater than $90 \%$ in patients with a low L/A ratios compared to approximately $30 \%$ in patients with high L/A ratios [28].

Leptin inhibition resulted in a decrease in the growth of tumours in animal and human studies [30]. Although antibodies against leptin receptors have been developed, these have yet to be tested as a CRC treatment [31]. A leptinderived peptide (L16) used to decorate the PEGylated liposomal doxorubicin (Doxil ${ }^{\circledR}$ ) has increased Doxil's therapeutic efficacy in a murine CRC model, thus showing promise as a future treatment to increase target efficacy to tumour cells [32].

\section{Reproductive system}

\section{Oestrogen}

Oestrogen's role in CRC is unclear. It was first observed in 1969, when Fraumeni [33] noticed an increased risk of breast and colon cancer in a group of nuns who have a longer and uninterrupted exposure to oestrogen [33]. Conversely, premenopausal women and post-menopausal women on combined hormone replacement therapy, which increases the level of oestrogen, have a lower incidence of CRC compared to age-matched men, thus refuting the oestrogen link [34].

There are three forms of oestrogen receptors: ER $\alpha, \operatorname{ER} \beta$ and G-protein coupled oestrogen receptor (GPR30) [35]. The first two are nuclear hormone receptors [36]. Although both $\operatorname{ER} \alpha$ and $\operatorname{ER} \beta$ are expressed to various other tissues in varying degrees, the main ER subtype in normal colonic epithelium is ER $\beta$ [36]. This is progressively lost as malignancy progresses, whilst ER $\alpha$ is increasingly expressed with CRC development [37].

Some studies show that ER $\beta$ is inversely correlated to prognosis although not all agree with this finding [37, 38]. Liu et al. [39] found that higher GPR30 expression in CRC tissue is associated with a better survival compared to lower GPR30 expression. However, further study is required to identify whether GPR30 is upregulated or downregulated in different patient cohorts and whether this can be used as a prognostic or therapeutic marker.

\section{Testosterone}

Testosterone, like oestrogen, is a steroid hormone. It is responsible for the secondary male sex characteristics and spermatogenesis. Its role in colon carcinogenesis is unclear as some studies show that lack of testosterone has a protective effect [40], and others increase the CRC risk [41]. Normal colonic epithelial tissue expresses both androgen receptor A and B (AR-A and AR-B), whilst CRC only expresses AR-A and they bind dihydrotestosterone (DHT) [42]. A third type of membrane ARs has been described, which is a G-protein coupled receptor and only found in colonic cancer cells (CaC02 and HCT116 cell lines) but not on normal colon cells [43]. Colon cancer tissue from xenografted tumours in mice, as well as the above cancer cells were used to show mAR-mediated tumour regression, thus showing promise as a novel therapeutic target [43].

Androgen's capacity as a prognostic factor in CRC has not been explored in literature as far as these authors have found.

\section{Pancreas and liver}

\section{Insulin and Insulin-like growth factor (IGF)}

Epidemiological studies have linked obesity with an increased risk of all cancers including CRC. Insulin resistance seems to play an important role and chronic hyperinsulinaemia, which is associated with type 2 diabetes mellitus (T2DM), is linked to increased levels of insulin-like growth factor binding protein 1 (IGFBP-1) and IGFBP-2. This in turn leads to increased IGF-1 which promotes cell proliferation [44]. There are six high-affinity-binding proteins (IGFBP-1 to IGFBP-6) in the circulation, which carry the IGF- 1 and -2 , and are readily measured in the circulation [44].

Higher IGFBP-2 or low IGFBP-3 plasma levels were associated with worse OS in CRC patients [45]. High levels of circulating IGF-1 or IGF-2 as well as high IGFR-1 activity have been linked to early relapse, independent of KRAS status [46].

Drugs targeting the insulin-IGF pathway have been under investigation: dalotuzumab, a humanized IgG1 anti-IGR1 antibody by Merck, has been tested as adjunct therapy to cetuximab-based therapy for chemorefractory, KRAS exon 2 mutant metastatic CRC case with no improvement in outcome [47]. Use of NT157, an inhibitor of IGF-1 receptor and STAT3, in APC mice, has been shown to reduce tumour burden and metastatic potential [48]. Finally IGF-1 receptor tyrosine kinase inhibitors (e.g. AXL, NVP-AEW541) have been investigated in animal and in in-vitro studies and have shown antineoplastic effects, especially when used with 5 -fluorouracil or cetuximab or fluvastatin $[49,50]$. These 
need further study to assess their clinical applicability to humans.

\section{Gastrointestinal tract}

\section{Pro-gastrin (PG)/gastrin (G)/gastrin-releasing peptide (GRP)}

Gastrin was initially discovered in 1905 as a major stimulant of acid secretion [51]. Gastrin releasing peptide (GRP) which is released from the vagus nerve, stimulates the release of gastrin from the $\mathrm{G}$ cells of the stomach. Gastric acid is secreted when gastrin binds to CCKBR receptors on enterochromaffin cells (ECL) and parietal cells. When the stomach $\mathrm{pH}$ decreases, the antral D cells release somatostatin, which in turn inhibits gastrin release from $\mathrm{G}$ cells [51]. The main products of the gastrin gene are the amidated forms of gastrin 17 and gastrin $34\left(\mathrm{G} 17-\mathrm{NH}_{2}\right.$ and $\left.\mathrm{G} 34-\mathrm{NH}_{2}\right)$. In $\mathrm{CRC}$, the non-amidated forms of gastrin are predominantly expressed. However, many studies investigating the link between gastrin and CRC, seem to measure only the amidated forms, which may be the reason for the conflicting evidence on the role of gastrin in CRC carcinogenesis [51]. It is also postulated that cancer cells lack the enzyme to convert PG to amidated forms of gastrin and as a result, cancer cells mainly produce PG [52].

PG which binds to annexin II (ANXII) receptor which is overexpressed in human CRC, can promote mitogenesis through various signaling pathways (nuclear factor-kB, Janus-activated kinase 2, signal transducer and activator of transcription 3, extracellular signal-regulated kinase, mitogen-activated protein kinase and phosphatidylinositol 3-kinase/Akt kinase) which can enhance tumour growth [53]. PG overexpression in patients with hyperplastic polyps showed a 5-year neoplasm-free survival rate of $38 \%$ compared to $100 \%$ patients who had none or low progastrin expression [54].

Najib et al. [52] have recently shown a role of PG in promoting angiogenesis in in vitro and in vivo conditions. Knocking down of PG expression in the tumour cells by shRNA has shown a significant decrease in vessel density, making PG an attractive therapeutic target in CRC [52].

Gastrin-releasing peptide (GRP) is a neuropeptide that, as the name suggests, stimulates gastrin release. GRP and its receptor (GRPR) are not normally expressed in colonic epithelial cells but seem to be overexpressed in colon, breast, pancreas and lung cancers [55]. Rivera et al. [55] showed that high expression of GRPR alone or both GRP and GRPR, are associated with delayed recurrence (14.1-17 months respectively, $p=0.005)$ and increased survival (10.1-13.1 months respectively, $\mathrm{p}=0.0124)$, as well as fewer lymph node metastases, making it an attractive prognostic marker [55]. Bombesin analagues (which bind to GRPR) have been used in radiolabelled form for imaging diagnosis, staging, recurrence detection and assessment of mestastasis in prostate cancer patients but have yet to be explored in CRC [56].

\section{Cholecystokinin (CCK)}

Cholecystokinin is produced by I cells of the proximal small bowel and has a role in digestion, appetite control and body weight regulation [57]. CCK binds to both of its $\mathrm{G}$ proteincoupled receptors (CCK1R and CCK2R) with high affinity. CCKR activation is implicated in proliferation, migration, differentiation, anti-apoptosis and inflammation and a single-nucleotide polymorphism in the CCKR gene has a prognostic potential in pancreatic cancer but not in CRC [58].

A recombinant immunotoxin (rCCK8PE38), which targets CCK2R, has been tested in 2 colon cancer cell lines (HCT-8, SW116) and one gastric cell line (MKN45) [58]. When nude mice were inoculated with HCT- 8 and then treated with this immunotoxin, tumour regression occurred, unlike the negative control group [58]. The exact mechanism of action CCK2R may differ in each cancer as mutated CCKR2 has been detected in pancreatic cancer but not in colorectal or gastric cancers [58]. Further study is needed to explore CCKR2 as a therapeutic target in CRC.

\section{Ghrelin}

Ghrelin is an orexigenic neuropeptide, which apart from increasing appetite, it causes growth hormone $(\mathrm{GH})$ release [59]. It is implicated in regulating metabolism, insulin release and inflammation [59]. Ghrelin and its receptor, Growth hormone secretagogue receptor $1 \alpha$ (GHSR $1 \alpha)$ are barely detectable in normal colonic epithelial cells but are significantly higher in cancer cell lines (Caco2 and SW480 cells) and CRC tissue [59]. So far, the ghrelin-GHSR axis have not shown to have a prognostic role [60]. Inhibition of the GHSR $1 \alpha$ using shRNA technology inhibits the growth of CRC cell line and xenografted tumour, suggesting GHSR 1 can be a target for novel future treatment for early colorectal adenocarcinoma [59].

\section{Guanylyl and uroguanylyl}

Guanylyl and uroguanylyl are both peptide hormones secreted by the small and large bowel. They are involved in maintaining epithelial homeostasis and fluid secretion via the guanylyl cyclase (GCC2C) [61]. GCC2C are naturally found in colonic epithelial cells but not in other tissues [61]. GCC2C is expressed in $95 \%$ of primary and metastatic CRCs, whilst uroguanylin and guanylin expression disappears early on in CRC tumorigenesis [61].

Oral supplementation with uroguanylin has shown promise in preventing polyps in mice and CRC proliferation, without serious adverse effects [62]. A Phase I trial using 
Adenovirus 5-human guanylyl cyclase C-PADRE vaccine on 10 patients, showed that $\mathrm{GCC} 2 \mathrm{C}$ vaccination is a safe and immunogenic target for cancer therapy [63]. Chimeric antigen receptors (CARs) used in mouse models with mestastatic CRC, eliminated metastases and increased survival, without toxicity [64]. Antibody-drug conjugates (ADCs), have also been used in a phase I clinical trial showing antitumor activity [65]. The commonest reported adverse effects included nausea, decreased appetite, fatigue, diarrhea, anaemia, alopecia and neutropenia [65]. Research into GCC2C target therapy is rapidly progressing and the next few years, will provide a better insight in its use in primary and metastatic CRC $[61,66]$.

\section{Neurotensin (NT)}

Neurotensin is a hormone mainly produced by the endocrine cells of the small bowel. Its main receptor, NTSR1, is undetectable in epithelial cells of normal colonic epithelium but moderately expressed in adenomas and adenocarcinomas [67]. Both in vivo and in vitro studies have shown that NT administration lead to colonic cancer proliferation [68].

Kamimae et al. [69] observed that epigenetic silencing of NTSR 1 gene by methylation is associated with better prognosis in colorectal cancer. As the impact of methylation on a gene depends on which $\mathrm{CpG}$ islands have been studied, so further study is required to explore the prognostic potential in CRC [68].

SR 48692, a NT antagonist, inhibits the stimulatory effect of NT on colon cancer cells in xenografted mouse models and recently has shown promise as a potential therapeutic target in gastric cancer as well $[68,70]$. Use of functionalized liposomes with NT peptide and filled with the cytotoxic doxorubicin in colon cancer cells, showed a better uptake of the drug and improved cytotoxicity [71]. Use of Neurotensin-Polyplex nanoparticles in murine cancer models has proven to be safe in patients with cancer expressing NTSR1 [72]. Clearly, NT has a role to play in CRC, but more work needs to be done to further explore its role in CRC.

\section{Somatostatin/somatotropin-release inhibiting factor (SRIF)}

Somatostatin is a peptide hormone produced by the GIT and the central nervous system and exists in 2 main forms: SRIF14 and SRIF-28. Evangelou I [73] measured the expression of two of the somatostatin receptor subtypes (Sst1 and Sst5) in 81 patients, showing a negative association between CRC invasion and liver metastasis. Patients with either Sst2 or Sst5 expression had longer survival rates, although this was not an independent predictor of survival after controlling for other known prognostic factors [73]. Cytotoxic SRIF agonist, AN-238 has been shown to inhibit colon cancer growth in CRC cell lines and xenografts, both ofwhich express Sst, regardless of their p53 status [74]. Further study is however required to establish the role of somatostatin in CRC.

\section{Neurokinin A, neurokinin $B$ and substance $P$}

Neurokinins (NK) and substance $\mathrm{P}$ (SP) are part of the tachykinin family, which are peptide hormones implicated in carcinogenesis. Chen et al. showed that high expression of its receptor, NK1R in CRC is associated with lymph node metastasis, TNM stage and worse survival [75]. Patients with higher SP expression also had a poorer prognosis (mean survival $43.53 \pm 2.4$ months) compared to patients with lower SP expression (mean survival time $79.98 \pm 1.60$ months) [75].

Garnier et al. [76] explored the therapeutic potential of NK1R antagonist, aprepitant (AP) by treating human colon cancer lines LiM6 ( $\beta$ catenin mutation) and DLD1 (APC mutation). Use of AP inhibited the growth of CRC cells through inhibition of the $\mathrm{Wnt} / \beta$-catenin and AKT/mTOR signaling pathways. The NK1R antagonists also inhibited the cancer stem cells (CSCs), which are thought to confer higher resistance to chemotherapy and radiotherapy and therefore play a key role in CRC recurrence [76].

\section{Central nervous system}

\section{Growth hormone}

Growth hormone $(\mathrm{GH})$ is a peptide hormone, secreted mainly by the pituitary gland. It acts directly on tissue or via IGF-1 through its action on the liver, promoting cell proliferation and differentiation [77]. Wang et al. [77] found that autocrine GH promoted cell proliferation, survival and oncogenicity of CRC cells in both in vitro and xenografted in vivo models. They also observed that the GH mRNA expression in CRC was associated with a larger tumor size and lymph node metastasis. Despite the evidence of GH implication in cancer, preclinical studies investigating the GHR antagonism as a therapeutic pathway for cancer treatment is limited.

Pegvisomant(B2036), which is an effective GHR blocker and used in patients with acromegaly, has shown limited use in preclinical studies because it behaves differently in nonhuman models [78]. Other alternative methods of inhibiting GHRs include: ATL1103, an antisense drug which blocks GHR (Antisense Therapeutics Ltd), a neutralizing GHR antibody and somatostatin agonists. In vitro and in vivo xenografted mouse model studies using siRNA knockdown of the GHR in human CRC cell line SW480, showed a reduced tumour growth and liver metastases [78]. Further studies, using GH antagonists should take into account, GH's closely related sequence similarity to prolactin, its interaction with 


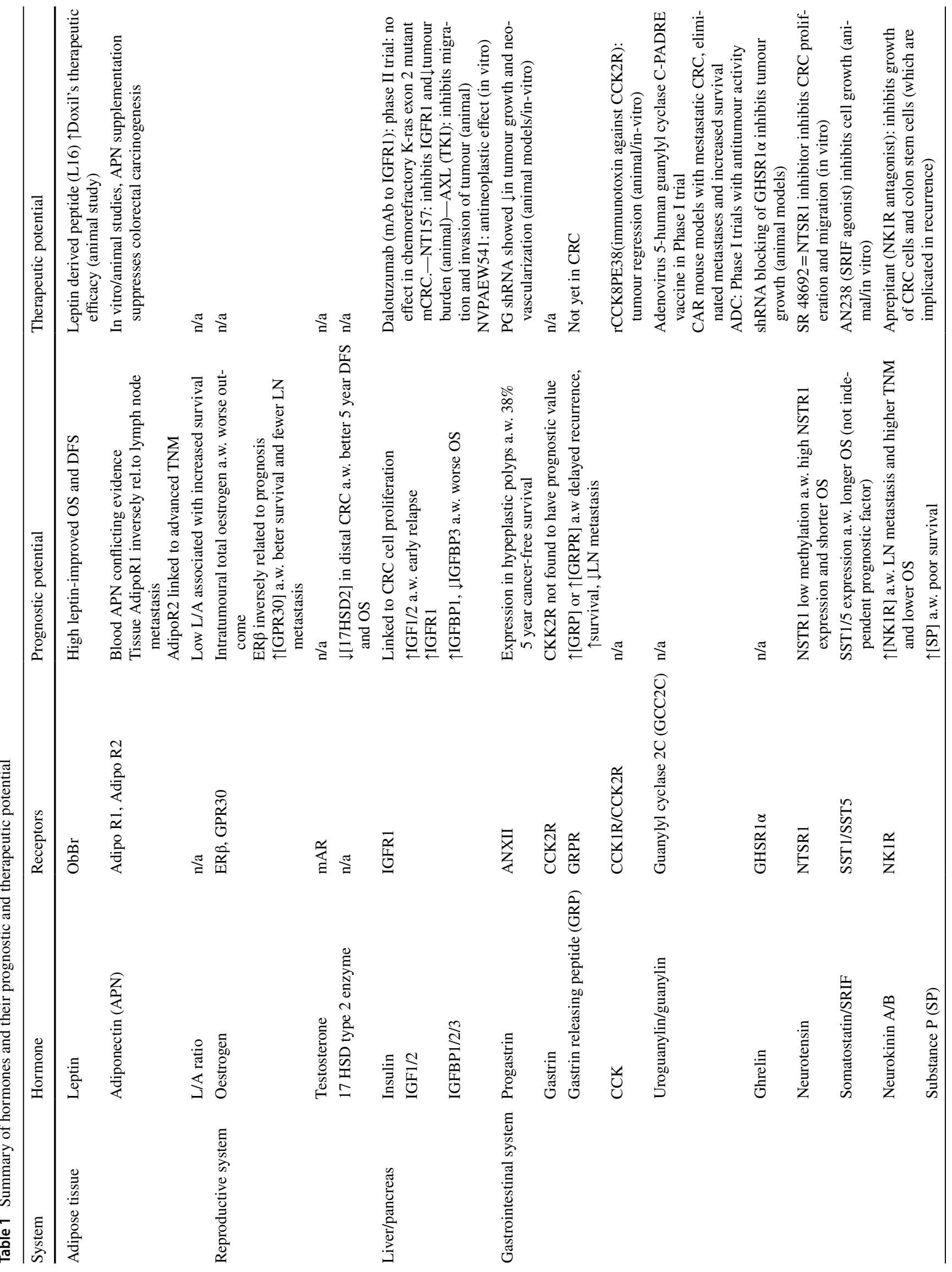


IGF1 receptors and epidermal growth factor receptors, to limit unwanted side-effects [78].

\section{Conclusions}

Colorectal cancer has shown to have a complex molecular pathway. The discovery of the role of hormones in breast and prostate cancer has changed the prognosis and treatment of its sufferers. Yet, hormonal links to CRC are not as clearly established. However, there is a lot of promise in the role of hormones in the prognostic and therapeutic role of hormones in CRC (Table 1). The link between obesity, T2DM and CRC is likely to be hormone-mediated in a certain subset of cancers. In addition, gut-derived hormones and their receptors show to be an attractive target, with uroguanylin/guanylin being the most promising. It is important to note that the action of hormones may share a common pathway in many of the other GI malignancies, posing a challenge in tailoring treatment strategies. Finally, this review has highlighted that only a small fraction of the hormones acting on the GIT has been investigated and those that have been investigated, are still mostly at an early stage of research and therefore need further study.

Acknowledgements We thank Dr. Anastasios Stavrou (anastasios. stavrou@leicester.ac.uk) of the Department of Molecular and Cell Biology at the University of Leicester, for his helpful comments on the manuscript.

Author contributions All authors have contributed significantly and are in agreement with the content of the manuscript.

Funding There was no funding source for this study.

\section{Compliance with ethical standards}

Conflict of interest The authors declare that they have no conflict of interest.

Open Access This article is distributed under the terms of the Creative Commons Attribution 4.0 International License (http://creativeco mmons.org/licenses/by/4.0/), which permits unrestricted use, distribution, and reproduction in any medium, provided you give appropriate credit to the original author(s) and the source, provide a link to the Creative Commons license, and indicate if changes were made.

\section{References}

1. Ronnekleiv-Kelly SM, Burkhart RA, Pawlik TM (2016) Molecular markers of prognosis and therapeutic targets in metastatic colorectal cancer. Surg Oncol 25(3):190-199. https://doi.org/10.1016/j. suronc.2016.05.018

2. Bredt LC, Rachid AF (2014) Predictors of recurrence after a first hepatectomy for colorectal cancer liver metastases: a 
retrospective analysis. World J Surg Oncol 12:391. https://doi. org/10.1186/1477-7819-12-391

3. Rehfeld JF (2015) Gastrointestinal hormone research-with a Scandinavian annotation. Scand J Gastroenterol 50(6):668-679. https://doi.org/10.3109/00365521.2015.1025831

4. Muppala S, Konduru SKP, Merchant N, Ramsoondar J, Rampersad CK, Rajitha B, Mukund V, Kancherla J, Hammond A, Barik TK, Mannarapu M, Alam A, Basha R, Bramhachari PV, Verma D, Sushma PS, Pattnaik S, Nagaraju GP (2017) Adiponectin: its role in obesity-associated colon and prostate cancers. Crit Rev Oncol/Hematol 116:125-133. https://doi.org/10.1016/j.critrevonc 2017.06.003

5. Riondino S, Roselli M, Palmirotta R, Della-Morte D, Ferroni P, Guadagni F (2014) Obesity and colorectal cancer: role of adipokines in tumor initiation and progression. World $\mathrm{J}$ Gastroenterol 20(18):5177-5190. https://doi.org/10.3748/wjg.v20.i18.5177

6. Gialamas SP, Petridou ET, Tseleni-Balafouta S, Spyridopoulos TN, Matsoukis IL, Kondi-Pafiti A, Zografos G, Mantzoros CS (2011) Serum adiponectin levels and tissue expression of adiponectin receptors are associated with risk, stage, and grade of colorectal cancer. Metabolism 60(11):1530-1538. https://doi. org/10.1016/j.metabol.2011.03.020

7. Fujisawa T, Endo H, Tomimoto A, Sugiyama M, Takahashi $\mathrm{H}$, Saito S, Inamori M, Nakajima N, Watanabe M, Kubota N, Yamauchi T, Kadowaki T, Wada K, Nakagama H, Nakajima A (2008) Adiponectin suppresses colorectal carcinogenesis under the high-fat diet condition. Gut 57(11):1531-1538. https://doi. org/10.1136/gut.2008.159293

8. Brakenhielm E, Veitonmaki N, Cao R, Kihara S, Matsuzawa Y, Zhivotovsky B, Funahashi T, Cao Y (2004) Adiponectininduced antiangiogenesis and antitumor activity involve caspasemediated endothelial cell apoptosis. Proc Natl Acad Sci USA 101(8):2476-2481

9. Gonullu G, Kahraman H, Bedir A, Bektas A, Yucel I (2010) Association between adiponectin, resistin, insulin resistance, and colorectal tumors. Int J Colorectal Dis 25(2):205-212. https://doi. org/10.1007/s00384-009-0828-6

10. Ferroni P, Palmirotta R, Spila A, Martini F, Raparelli V, Fossile E, Mariotti S, Del Monte G, Buonomo O, Roselli M, Guadagni F (2007) Prognostic significance of adiponectin levels in nonmetastatic colorectal cancer. Anticancer Res 27(1b):483-489

11. Chong DQ, Mehta RS, Song M, Kedrin D, Meyerhardt JA, Ng K, Wu K, Fuchs CS, Giovannucci EL, Ogino S, Chan AT (2015) Prediagnostic plasma adiponectin and survival among patients with colorectal cancer. Cancer Prev Res (Philadelphia Pa) 8(12):11381145. https://doi.org/10.1158/1940-6207.capr-15-0175

12. Ayyildiz T, Dolar E, Ugras N, Adim SB, Yerci O (2014) Association of adiponectin receptor (Adipo-R1/-R2) expression and colorectal cancer. Asian Pac J Cancer Prev 15(21):9385-9390

13. Sakellariou S, Fragkou P, Levidou G, Gargalionis AN, Piperi C, Dalagiorgou G, Adamopoulos C, Saetta A, Agrogiannis G, Theohari I, Sougioultzis S, Tsioli P, Karavokyros I, Tsavaris N, Kostakis ID, Zizi-Serbetzoglou A, Vandoros GP, Patsouris E, Korkolopoulou P (2016) Clinical significance of AGE-RAGE axis in colorectal cancer: associations with glyoxalase-I, adiponectin receptor expression and prognosis. BMC Cancer 16:174. https:// doi.org/10.1186/s12885-016-2213-5

14. Choe EK, Yi JW, Chai YJ, Park KJ (2018) Upregulation of the adipokine genes ADIPOR1 and SPP1 is related to poor survival outcomes in colorectal cancer. J Surg Oncol. https://doi.org/10.1002/ jso. 25078

15. Canhoroz M, Kanat O, Saraydaroglu O, Buluc E, Avci N, Cubukcu E, Olmez OF, Manavoglu O (2014) Clinical significance of adiponectin expression in colon cancer patients. J Cancer Res Ther 10(2):347-353. https://doi.org/10.4103/0973-1482.136634
16. Duan B-S, Xie L-F, Wang YUE (2017) Aberrant methylation of T-cadherin can be a diagnostic biomarker for colorectal cancer. Cancer Genomics Proteomics 14(4):277-284. https://doi. org/10.21873/cgp. 20038

17. Kim AY, Lee YS, Kim KH, Lee JH, Lee HK, Jang S-H, Kim S-E, Lee GY, Lee J-W, Jung S-A, Chung HY, Jeong S, Kim JB (2010) Adiponectin represses colon cancer cell proliferation via AdipoR1- and -R2-mediated AMPK activation. Mol Endocrinol 24(7):1441-1452. https://doi.org/10.1210/me.2009-0498

18. Nigro E, Schettino P, Polito R, Scudiero O, Monaco ML, De Palma GD, Daniele A (2018) Adiponectin and colon cancer: evidence for inhibitory effects on viability and migration of human colorectal cell lines. Mol Cell Biochem. https://doi.org/10.1007/ s11010-018-3319-7

19. Malih S, Najafi R (2015) AdipoRon: a possible drug for colorectal cancer prevention? Tumour Biol 36(9):6673-6675. https://doi. org/10.1007/s13277-015-3911-3

20. Kawashima K, Maeda K, Saigo C, Kito Y, Yoshida K, Takeuchi T (2017) Adiponectin and intelectin-1: important adipokine players in obesity-related colorectal carcinogenesis. Int J Mol Sci 18(4). https://doi.org/10.3390/ijms18040866

21. Endo H, Hosono K, Uchiyama T, Sakai E, Sugiyama M, Takahashi H, Nakajima N, Wada K, Takeda K, Nakagama H, Nakajima A (2011) Leptin acts as a growth factor for colorectal tumours at stages subsequent to tumour initiation in murine colon carcinogenesis. Gut 60(10):1363-1371. https://doi.org/10.1136/ gut.2010.235754

22. Tamakoshi K, Toyoshima H, Wakai K, Kojima M, Suzuki K, Watanabe Y, Hayakawa N, Yatsuya H, Kondo T, Tokudome S, Hashimoto S, Suzuki S, Kawado M, Ozasa K, Ito Y, Tamakoshi A (2005) Leptin is associated with an increased female colorectal cancer risk: a nested case-control study in Japan. Oncology 68(4-6):454-461. https://doi.org/10.1159/000086988

23. Rouet-Benzineb P, Aparicio T, Guilmeau S, Pouzet C, Descatoire V, Buyse M, Bado A (2004) Leptin counteracts sodium butyrateinduced apoptosis in human colon cancer HT-29 cells via NFkappaB signaling. J Biol Chem 279(16):16495-16502. https:// doi.org/10.1074/jbc.M312999200

24. Paik KY, Lee IK, Lee YS, Sung NY, Kwon TS (2014) Clinical implications of systemic inflammatory response markers as independent prognostic factors in colorectal cancer patients. Cancer Res Treat 46(1):65-73. https://doi.org/10.4143/ crt.2014.46.1.65

25. Uddin S, Bavi PP, Hussain AR, Alsbeih G, Al-Sanea N, Abduljabbar A, Ashari LH, Alhomoud S, Al-Dayel F, Ahmed M, AlKuraya KS (2009) Leptin receptor expression in Middle Eastern colorectal cancer and its potential clinical implication. Carcinogenesis 30(11):1832-1840. https://doi.org/10.1093/carci n/bgp145

26. Wang D, Chen J, Chen H, Duan Z, Xu Q, Wei M, Wang L, Zhong $M$ (2012) Leptin regulates proliferation and apoptosis of colorectal carcinoma through PI3K/Akt/mTOR signalling pathway. J Biosci 37(1):91-101

27. Jeong WK, Baek SK, Kim MK, Kwon SY, Kim HS (2015) Prognostic significance of tissue leptin expression in colorectal cancer patients. Ann Coloproctol 31(6):222-227. https://doi.org/10.3393/ ac.2015.31.6.222

28. Guadagni F, Roselli M, Martini F, Spila A, Riondino S, D’Alessandro R, Del Monte G, Formica V, Laudisi A, Portarena I, Palmirotta R, Ferroni P (2009) Prognostic significance of serum adipokine levels in colorectal cancer patients. Anticancer Res 29(8):3321-3327

29. Wei EK, Giovannucci E, Fuchs CS, Willett WC, Mantzoros CS (2005) Low plasma adiponectin levels and risk of colorectal cancer in men: a prospective study. J Natl Cancer Inst 97(22):16881694. https://doi.org/10.1093/jnci/dji376 
30. Zhou W, Tian Y, Gong H, Guo S, Luo C (2014) Oncogenic role and therapeutic target of leptin signaling in colorectal cancer. Expert Opin Ther Targets 18(8):961-971. https://doi. org/10.1517/14728222.2014.926889

31. Zabeau L, Verhee A, Catteeuw D, Faes L, Seeuws S, Decruy T, Elewaut D, Peelman F, Tavernier J (2012) Selection of noncompetitive leptin antagonists using a random nanobody-based approach. Biochem J 441(1):425-434. https://doi.org/10.1042/ bj20110438

32. Amiri Darban S, Nikoofal-Sahlabadi S, Amiri N, Kiamanesh N, Mehrabian A, Zendehbad B, Gholizadeh Z, Jaafari MR (2018) Targeting the leptin receptor: to evaluate therapeutic efficacy and anti-tumor effects of Doxil, in vitro and in vivo in mice bearing C26 colon carcinoma tumor. Colloids Surf B 164:107-115

33. Foster PA (2013) Oestrogen and colorectal cancer: mechanisms and controversies. Int J Colorectal Dis 28(6):737-749. https://doi. org/10.1007/s00384-012-1628-y

34. Brenner H, Hoffmeister M, Arndt V, Haug U (2007) Gender differences in colorectal cancer: implications for age at initiation of screening. Br J Cancer 96(5):828-831. https://doi.org/10.1038/ sj.bjc. 6603628

35. Parks M, Tillhon M, Dona F, Prosperi E, Scovassi AI (2011) 2-Methoxyestradiol: new perspectives in colon carcinoma treatment. Mol Cell Endocrinol 331(1):119-128. https://doi. org/10.1016/j.mce.2010.08.017

36. Louie MC, Sevigny MB (2017) Steroid hormone receptors as prognostic markers in breast cancer. Am J Cancer Res 7(8):1617-1636

37. Chen J, Iverson D (2012) Estrogen in obesity-associated colon cancer: friend or foe? Protecting postmenopausal women but promoting late-stage colon cancer. Cancer Causes Control 23(11):1767-1773. https://doi.org/10.1007/s10552-012-0066-Z

38. Stevanato Filho PR, Aguiar Junior S, Begnami MD, Ferreira FO, Nakagawa WT, Spencer R, Bezerra TS, Boggiss PE, Lopes A (2017) Estrogen receptor beta as a prognostic marker of tumor progression in colorectal cancer with familial adenomatous polyposis and sporadic polyps. Pathol Oncol Res 05:05

39. Liu Q, Chen Z, Jiang G, Zhou Y, Yang X, Huang H, Liu H, Du J, Wang H (2017) Epigenetic down regulation of G protein-coupled estrogen receptor (GPER) functions as a tumor suppressor in colorectal cancer. Mol Cancer 16(1):87. https://doi.org/10.1186/s1294 3-017-0654-3

40. Amos-Landgraf JM, Heijmans J, Wielenga MC, Dunkin E, Krentz KJ, Clipson L, Ederveen AG, Groothuis PG, Mosselman S, Muncan V, Hommes DW, Shedlovsky A, Dove WF, van den Brink GR (2014) Sex disparity in colonic adenomagenesis involves promotion by male hormones, not protection by female hormones. Proc Natl Acad Sci USA 111(46):16514-16519. https://doi. org/10.1073/pnas.1323064111

41. Gillessen S, Templeton A, Marra G, Kuo YF, Valtorta E, Shahinian VB (2010) Risk of colorectal cancer in men on long-term androgen deprivation therapy for prostate cancer. J Natl Cancer Inst 102(23):1760-1770. https://doi.org/10.1093/jnci/djq419

42. Roshan MH, Tambo A, Pace NP (2016) The role of testosterone in colorectal carcinoma: pathomechanisms and open questions. EPMA J 7:22. https://doi.org/10.1186/s13167-016-0071-5

43. Gu S, Papadopoulou N, Nasir O, Foller M, Alevizopoulos K, Lang F, Stournaras C (2011) Activation of membrane androgen receptors in colon cancer inhibits the prosurvival signals Akt/bad in vitro and in vivo and blocks migration via vinculin/actin signaling. Mol Med 17(1-2):48-58. https://doi.org/10.2119/molme d.2010.00120

44. Renehan AG, Frystyk J, Flyvbjerg A (2006) Obesity and cancer risk: the role of the insulin-IGF axis. Trends Endocrinol Metab 17(8):328-336. https://doi.org/10.1016/j.tem.2006.08.006
45. Lochhead P, Imamura Y, Morikawa T, Kuchiba A, Yamauchi M, Liao X, Qian ZR, Nishihara R, Wu K, Meyerhardt JA, Fuchs CS, Ogino S (2012) Insulin-like growth factor 2 messenger RNA binding protein 3 (IGF2BP3) is a marker of unfavourable prognosis in colorectal cancer. Eur J Cancer (Oxford England 1990) 48(18):3405-3413. https://doi.org/10.1016/j.ejca.2012.06.021

46. Lee J, Jain A, Kim P, Lee T, Kuller A, Princen F, In G, Kim SH, Park JO, Park YS, Singh S, Kim HC (2014) Activated cMET and IGF1R-driven PI3K signaling predicts poor survival in colorectal cancers independent of KRAS mutational status. PloS ONE 9(8):e103551. https://doi.org/10.1371/journal.pone.01035 51

47. Sclafani F, Kim TY, Cunningham D, Kim TW, Tabernero J, Schmoll HJ, Roh JK, Kim SY, Park YS, Guren TK, Hawkes E, Clarke SJ, Ferry D, Frodin JE, Ayers M, Nebozhyn M, Peckitt C, Loboda A, Watkins DJ (2017) Dalotuzumab in chemorefractory KRAS exon 2 mutant colorectal cancer: results from a randomised phase II/III trial. Int J Cancer 140(2):431-439. https:// doi.org/10.1002/ijc.30453

48. Sanchez-Lopez E, Flashner-Abramson E, Shalapour S, Zhong Z, Taniguchi K, Levitzki A, Karin M (2016) Targeting colorectal cancer via its microenvironment by inhibiting IGF-1 Receptorinsulin receptor substrate and STAT3 signaling. Oncogene 35(20):2634-2644. https://doi.org/10.1038/onc.2015.326

49. Uribe DJ, Mandell EK, Watson A, Martinez JD, Leighton JA, Ghosh S, Rothlin CV (2017) The receptor tyrosine kinase AXL promotes migration and invasion in colorectal cancer. PloS ONE 12(7):e0179979. https://doi.org/10.1371/journal.pone.0179979

50. Hopfner M, Sutter AP, Huether A, Baradari V, Scherubl H (2006) Tyrosine kinase of insulin-like growth factor receptor as target for novel treatment and prevention strategies of colorectal cancer. World J Gastroenterol 12(35):5635-5643

51. Chueca E, Lanas A, Piazuelo E (2012) Role of gastrin-peptides in Barrett's and colorectal carcinogenesis. World J Gastroenterol 18(45):6560-6570. https://doi.org/10.3748/wjg.v18.i45.6560

52. Najib S, Kowalski-Chauvel A, Do C, Roche S, Cohen-JonathanMoyal E, Seva C (2015) Progastrin a new pro-angiogenic factor in colorectal cancer. Oncogene 34(24):3120-3130

53. Ferrand A, Bertrand C, Portolan G, Cui G, Carlson J, Pradayrol L, Fourmy D, Dufresne M, Wang TC, Seva C (2005) Signaling pathways associated with colonic mucosa hyperproliferation in mice overexpressing gastrin precursors. Can Res 65(7):2770-2777. https://doi.org/10.1158/0008-5472.Can-04-0978

54. Do C, Bertrand C, Palasse J, Delisle MB, Shulkes A, Cohen-Jonathan-Moyal E, Ferrand A, Seva C (2012) A new biomarker that predicts colonic neoplasia outcome in patients with hyperplastic colonic polyps. Cancer Prev Res (Philadelphia Pa) 5(4):675-684. https://doi.org/10.1158/1940-6207.Capr-11-0408

55. Rivera CA, Ahlberg NC, Taglia L, Kumar M, Blunier A, Benya RV (2009) Expression of GRP and its receptor is associated with improved survival in patients with colon cancer. Clin Exp Metastasis 26(7):663-671. https://doi.org/10.1007/s10585-009-9265-8

56. Baratto L, Jadvar H, Iagaru A (2017) Prostate cancer theranostics targeting gastrin-releasing peptide receptors. Mol Imaging Biol. https://doi.org/10.1007/s11307-017-1151-1

57. Tripathi S, Flobak A, Chawla K, Baudot A, Bruland T, Thommesen L, Kuiper M, Lægreid A (2015) The gastrin and cholecystokinin receptors mediated signaling network: a scaffold for data analysis and new hypotheses on regulatory mechanisms. BMC Syst Biol 9:40. https://doi.org/10.1186/s12918-015-0181-z

58. Alsubai J, Matters GL, McGovern CO, Liao J, Gilius EL, Smith JP (2016) Germline mutation of the CCK receptor: a novel biomarker for pancreas cancer. Clin Transl Gastroenterol 7:e134. https://doi. org/10.1038/ctg.2015.61 
59. Liu A, Huang CG, Xu J, Cai XH (2016) Lentivirus-mediated shRNA interference of ghrelin receptor blocks proliferation in the colorectal cancer cells. Cancer Med 5(9):2417-2426. https:// doi.org/10.1002/cam4.723

60. Waseem T, Javaid Ur R, Ahmad F, Azam M, Qureshi MA (2008) Role of ghrelin axis in colorectal cancer: a novel association. Peptides 29(8):1369-1376. https://doi.org/10.1016/j.pepti des.2008.03.020

61. Aka AA, Rappaport JA, Pattison AM, Sato T, Snook AE, Waldman SA (2017) Guanylate cyclase $C$ as a target for prevention, detection, and therapy in colorectal cancer. Expert Rev Clin Pharmacol 10(5):549-557. https://doi.org/10.1080/17512 433.2017.1292124

62. Pitari GM, Di Guglielmo MD, Park J, Schulz S, Waldman SA (2001) Guanylyl cyclase C agonists regulate progression through the cell cycle of human colon carcinoma cells. Proc Natl Acad Sci USA 98(14):7846-7851. https://doi.org/10.1073/pnas.141124698

63. Snook A, Baybutt T, Mastrangelo M, Lewis N, Goldstein S, Kraft W, Oppong Y, Hyslop T, Myers R, Alexeev V, Eisenlohr L, Sato T, Waldman S (2015) A Phase I study of AD5-GUCY2C-PADRE in stage I and II colon cancer patients. J Immunother Cancer 3(Suppl 2):P450-P450. https://doi.org/10.1186/2051-1426-3-S2-P450

64. Magee MS, Kraft CL, Abraham TS, Baybutt TR, Marszalowicz GP, Li P, Waldman SA, Snook AE (2016) GUCY2C-directed CAR-T cells oppose colorectal cancer metastases without autoimmunity. Oncoimmunology 5(10):e1227897. https://doi. org/10.1080/2162402x.2016.1227897

65. Almhanna K, Kalebic T, Cruz C, Faris JE, Ryan DP, Jung J, Wyant T, Fasanmade AA, Messersmith W, Rodon J (2016) Phase I study of the investigational anti-guanylyl cyclase antibody-drug conjugate TAK-264 (MLN0264) in adult patients with advanced gastrointestinal malignancies. Clin Cancer Res 22(20):5049-5057. https://doi.org/10.1158/1078-0432.Ccr-15-2474

66. Gallery M, Zhang J, Bradley DP, Brauer P, Cvet D, Estevam J, Danaee H, Greenfield E, Li P, Manfredi M, Loke HK, Rabino C, Stringer B, Williamson M, Wyant T, Yang J, Zhu Q, Abu-Yousif A, Veiby OP (2018) A monomethyl auristatin E-conjugated antibody to guanylyl cyclase $\mathrm{C}$ is cytotoxic to target-expressing cells in vitro and in vivo. PloS ONE 13(1):e0191046. https://doi. org/10.1371/journal.pone.0191046

67. Gui X, Guzman G, Dobner PR, Kadkol SS (2008) Increased neurotensin receptor-1 expression during progression of colonic adenocarcinoma. Peptides 29(9):1609-1615. https://doi. org/10.1016/j.peptides.2008.04.014

68. Qiu S, Pellino G, Fiorentino F, Rasheed S, Darzi A, Tekkis P, Kontovounisios C (2017) A review of the role of neurotensin and its receptors in colorectal cancer. Gastroenterol Res Pract 2017:6456257

69. Kamimae S, Yamamoto E, Kai M, Niinuma T, Yamano HO, Nojima M, Yoshikawa K, Kimura T, Takagi R, Harada E, Harada
T, Maruyama R, Sasaki Y, Tokino T, Shinomura Y, Sugai T, Imai $\mathrm{K}$, Suzuki H (2015) Epigenetic silencing of NTSR1 is associated with lateral and noninvasive growth of colorectal tumors. Oncotarget 6(30):29975-29990. https://doi.org/10.18632/oncot arget.5034

70. Akter H, Yoon JH, Yoo YS, Kang MJ (2018) Validation of neurotensin receptor 1 as a therapeutic target for gastric cancer. Mol Cells. https://doi.org/10.14348/molcells.2018.0025

71. Falciani C, Accardo A, Brunetti J, Tesauro D, Lelli B, Pini A, Bracci L, Morelli G (2011) Target-selective drug delivery through liposomes labeled with oligobranched neurotensin peptides. ChemMedChem 6(4):678-685. https://doi.org/10.1002/ cmdc. 201000463

72. Hernandez ME, Rembao JD, Hernandez-Baltazar D, CastilloRodriguez RA, Tellez-Lopez VM, Flores-Martinez YM, OrozcoBarrios CE, Rubio HA, Sanchez-Garcia A, Ayala-Davila J, Arango-Rodriguez ML, Pavon L, Mejia-Castillo T, Forgez P, Martinez-Fong D (2014) Safety of the intravenous administration of neurotensin-polyplex nanoparticles in BALB/c mice. Nanomedicine 10(4):745-754. https://doi.org/10.1016/j.nano.2013.11.013

73. Evangelou I, Petraki C, Msaouel P, Scorilas A, Sdrolia E, Padazi G, Koborozos V, Koutsilieris M (2012) Immunohistochemical expression of somatostatin receptor subtypes 2 and 5 in colorectal cancer. Eur J Clin Invest 42(7):777-783. https://doi.org/10.11 11/j.1365-2362.2012.02648.x

74. Szepeshazi K, Schally AV, Halmos G, Armatis P, Hebert F, Sun B, Feil A, Kiaris H, Nagy A (2002) Targeted cytotoxic somatostatin analogue AN-238 inhibits somatostatin receptor-positive experimental colon cancers independently of their p53 status. Can Res 62(3):781-788

75. Chen XY, Ru GQ, Ma YY, Xie J, Chen WY, Wang HJ, Wang SB, Li L, Jin KT, He XL, Mou XZ (2016) High expression of substance $\mathrm{P}$ and its receptor neurokinin-1 receptor in colorectal cancer is associated with tumor progression and prognosis. Oncotargets Therapy 9:3595-3602. https://doi.org/10.2147/ott.s102356

76. Garnier A, Vykoukal J, Hubertus J, Alt E, von Schweinitz D, Kappler R, Berger M, Ilmer M (2015) Targeting the neurokinin-1 receptor inhibits growth of human colon cancer cells. Int J Oncol 47(1):151-160. https://doi.org/10.3892/ijo.2015.3016

77. Wang JJ, Chong QY, Sun XB, You ML, Pandey V, Chen YJ, Zhuang QS, Liu DX, Ma L, Wu ZS, Zhu T, Lobie PE (2017) Autocrine hGH stimulates oncogenicity, epithelial-mesenchymal transition and cancer stem cell-like behavior in human colorectal carcinoma. Oncotarget 8(61):103900-103918

78. Perry JK, Wu ZS, Mertani HC, Zhu T, Lobie PE (2017) Tumourderived human growth hormone as a therapeutic target in oncology. Trends Endocrinol Metab 28(8):587-596 